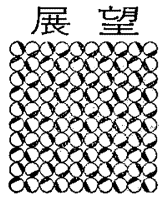

\title{
高分子系廃棄物燃焼炉の問題点
}

廃萊物の烍却炉の代表は，都市じんかい焼却炉である。最近都市じんかい中 にプラスチックが混入し，しだいにその量が多くなってきたため、これらの㜔 却炉に種々の障害が起きつつある。元来, 高分子系のものは, 他のゴミとまっ たく性質が違らので，現在の技術では，これをいっしょにして，完全に焼却し ようとするのに問題がある。高分子系の燃焼特性をつかみ, 暗却上の問題点を 解決することが,この問題解決の重要な要素となるであるら。

織田武*

\section{1. 高分子系庇寨物焼却処理の現状}

プラスチックは耐薬品性，耐腐食性，耐老化性にすぐ れ，電気的特性，成形性がよいなどの材料特性から各種 工業材料として広く利用され，日常生活に欠かせないる のとなってきた。それ伴い，プラスチック廃裹物が年 々增加し，先の対策が現在大きな社会的問題となってき ている。これら高分子系廃衰物は, 都市系と産業系火大 別されるが，都市系の廢䔞物忹一般の家庭から排出され るゴミで，年々ゴミ中に含まれるプラスチックの量の増 加のため, 都市ゴミ焼却炉に種々の障害を起こしつつあ る。一方，産業系の高分子廃棄物怯，比較的分別しやす く，組成も一定であるので処理はしやすいとい光よう。 処理が技術的飞困難とされているの性，前者の都市系の 廃莗物で, とくに高分子系が問題になるのは，穴の燃焼特 性が他のセルロース系を主体とした一般ゴミとまったく 異なるためである。プラスデックは発熱量が一般ゴミに 比べて数倍以上高く，燃焼に際して必要な空気もゴミの 数倍必要で，そのう党然焼炕よて有害で腐食性の強い ガスを放出するなどの然焼特性から，元来セルロース系 のゴミを対象济設されている。都市ゴミ焼却炉飞対 し，種々の障害をむたらす結果となってきている。この ような点から，都市系，産業系を問わず，高分子系廃棄 物を分別，収集し，それらの専燒处理の必要性がクロ一 ズアップしてきている。

高分子系廃棄物の処理方法性，焼却，埋め立て，資源 化に大別されている。そのらち，埋立て処分は用地の確 保，水質污濁などの二次公害の問題などで，年々処分が

* Takeshi $\mathrm{O}_{\mathrm{DA}}$ 株式会仆:タクマ 環境開発本部技術 部（530大阪市北区堂島中 1-16-1）次長
困難になりつつある。資源化は従来，単純再生として行 なわれてきた以外飞，溶融固化による製品化，ガス化， 燃料化など次々と新しい試みがなされてきている。しか しながら，ここ当分は焼却処理が 主体となるであうう 乙, 焼却処理は最終的で, 最も安全かつ確実な処理とい うことができる。

\section{2. プラスチックの燃焼特性}

\section{2-1. 燃焼の形態}

固体の燃焼は表面燃焼と分解燃燒々蒸発燃焼の三つの 形態に大別される。プラスチックの燃焼は主として分解 然焼であり，組成成分の沸点が比较的高いプラスチック の場合，蒸発燃焼は，ほとんどみられない。プラスチッ クを加熱すると，比較的低分子のガスが発生し，気相に よる燃焼を行なう。熱炕より溶融，軟化する大部分の熱 可塑性樹脂特よび，熱てよって液化しない多くの熱硬化 性樹脂はこの分解燃焼系体をとる。林燃焼のように，溶 解した液面上に火焱を出して然堿する，いわゆるプール 燃焼もこの分解燃焼である。一方，フェノール，メラミ ンなどの熱硬化性のものは分解燃焼之同時に，之の形状 を保ちつつ表面然䈳も進行する。

\section{2-2. 燃焼生成物}

一般にプラスチックの熱分解生成物としては，主とし て低沸点ガス，高沸点ガス，タール分，残留物に大別さ れる。ガスは通常複雑多種で，たと党ばポリプロピレン の場合, 分解生成物として 16 種類もの炭化水素が認め られる。さらに然焼のよう酸索が加方る場合, その酸 化物が考党られ，性るか複雑多種の生成物を生ずるこ とになる。燃燒生成物として問題になるのは，これらの 炭化水素が不完全燃焼で分解せずそのまま排がス中に存 在することと塩化水素，シアン化水素などの有害成分， 一酸化炭素，スス，特よび鉛，カドミウムなどの重金属 


\begin{tabular}{|c|c|c|c|c|c|c|c|c|c|c|}
\hline & $\begin{array}{l}\text { ポリスチ } \\
\text { レン }\end{array}$ & 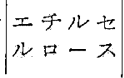 & サラン & 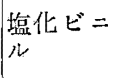 & ナイロソ| & レーヨン & 羊 毛 & 生 糸 & 木 材 & 紙 \\
\hline 一酸化炭素 & 0.174 & 0.440 & 0.022 & 0.229 & 0.304 & 0.116 & 0.446 & 0.634 & 0.270 & 0.135 \\
\hline 二酸化炭素 & 2.192 & 2.294 & 1.047 & 0.433 & 1.226 & 1.836 & 1.451 & 1.352 & 1.626 & 1.202 \\
\hline ホスゲン & 一 & $\longrightarrow$ & 一 & 0.0001 & - & 一 & 一 & 一 & - & 一 \\
\hline シアソ化水素 & - & 一 & 一 & - & 0.0076 & 一 & 0.007 & 0.036 & $\cdots$ & $\longrightarrow$ \\
\hline 塩化水素 & - & 一 & 0.621 & 0.496 & - & 一 & trace & 一 & 一 & 一 \\
\hline アルデヒド類 & - & - & 一 & 一 & 0.0064 & - & - & 0.0024 & trace & 一 \\
\hline 酸（酢酸など） & - & 一 & 一 & - & - & 一 & - & 一 & 一 & 0.0009 \\
\hline アンモニア & 一 & 一 & - & - & 0.032 & - & 一 & 0.053 & 一 & 一 \\
\hline
\end{tabular}

いぶる

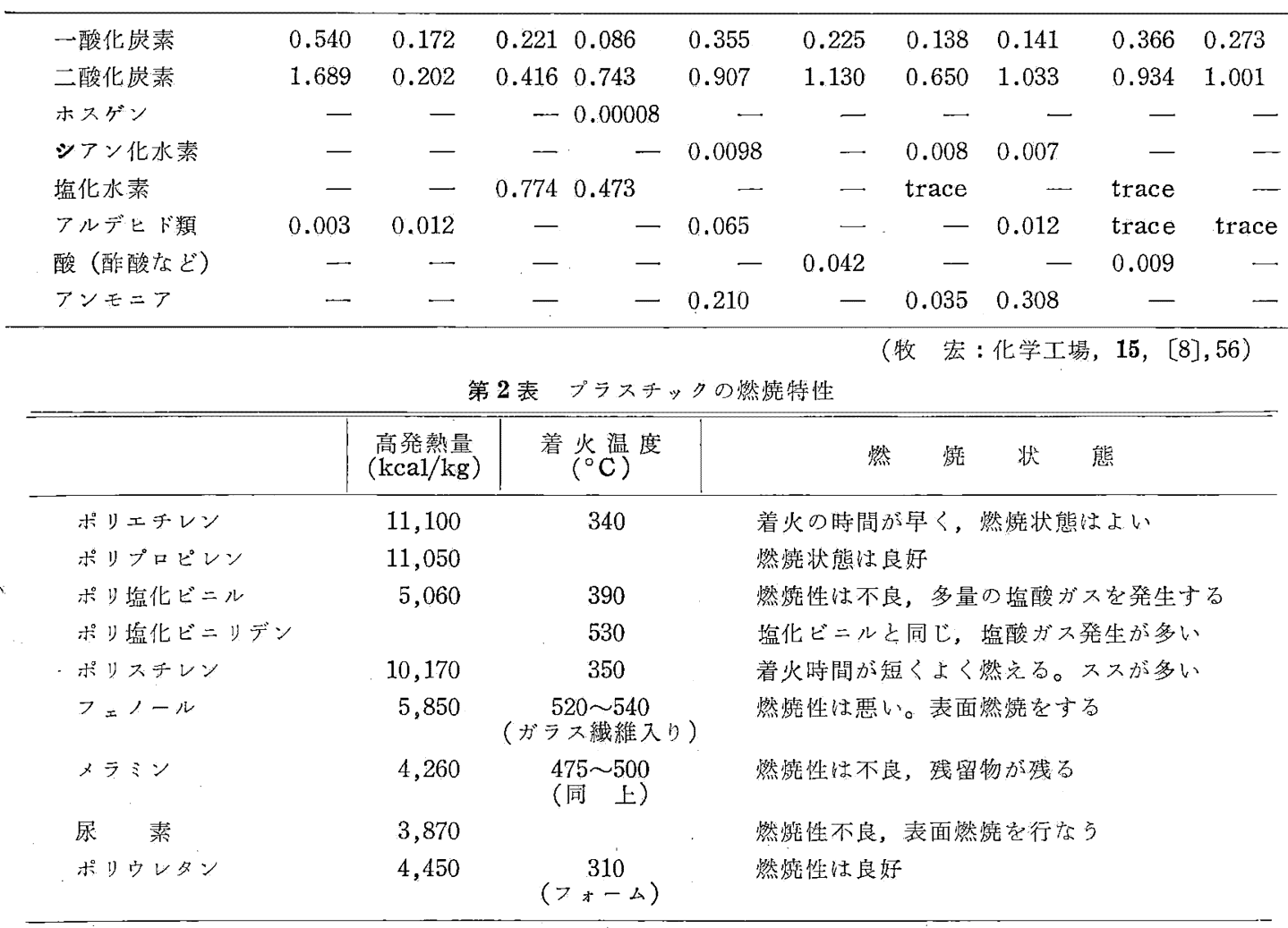

類である。これらのうち, 炭化水素, CO, シアン化水素 などは，完全然焼を行なうことによって除去が比較的容 易であるが，塩化水素，重金属などの有害成分は燃焼で は，除去は不可能で，特別な排ガス処理が必要となる。

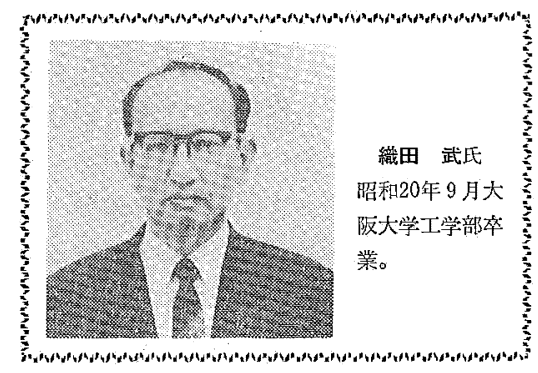

大スはばいじんの大部分を占めるものであるが，その 発生防止は可能であり，そのため種々な形式の暁却炉 が開発されてきている。第 1 表にプラスチックと他の材 料の然焼生成物を示吉。

\section{2-3. 熱分解特性}

プラスチックは発熱量が高く，燒却時高温になりやす い。実際にはプラスチックの種類により発熱量にかなり の幅功すり,そのう党可塑剤, 難燃剂の添加量などの影響 で,然焼性にかなりの相違がある。第 2 表にプラスチック の然焼特性を示した。表中の着火温度はプラステックが 熱分解して発生したガスに㶩がつく温度を示している。 第 1 図は各種プラスチックの熱分解曲線である。図に 


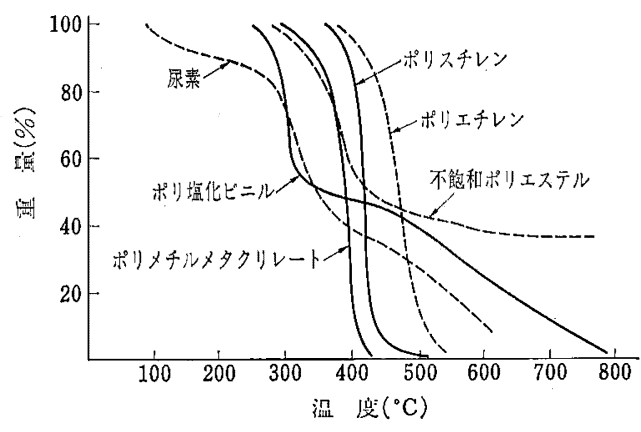

第 1 図 プラスチックの熱分解曲線

よると，塩化ビニル以外のプラスチックは $300^{\circ} \mathrm{C}$ 以上 で分解が始まり， $400 \sim 500^{\circ} \mathrm{C}$ で分解が終了するが，塩 化ビニルは $300^{\circ} \mathrm{C}$ 前後で一度分解に上る重量減が約半 分で終り,さらに $500^{\circ} \mathrm{C}$ ぐらいから再分解して重量を 減少する。塩化ビニル以外のポリェテレン，ステレンな ぞは，炭化水素ガス発生による単純な分解曲線であるの 飞対し, 塩化ビニルの場合の $300^{\circ} \mathrm{C}$ 前後での分解は, 含有する塩素が塩酸ガスとして脱塩酸反応に上る分解重 量隇の曲線であり， $500^{\circ} \mathrm{C}$ 以降で始めて炭化水素ガス 発生汇よる分解経過をたどるという特性を示す。このこ とは塩化ビニルを処理するう党について考虑すべき重要 な特性である。

プラステックは発熱量が高いため, 燃焼に際して多量 の空気を必要とする。第 2 図に各種プラスチックの低発 熱量と理諭空気量，理諭燃焼ガス量の関係を図示した。 塩化ビニル，ポリェチレンの理論空気量は，それ卆れ $4.3 \mathrm{Nm}^{3} / \mathrm{kg}, 11.4 \mathrm{Nm}^{3} / \mathrm{kg}$ であり，実際燃焼にあたっ ては理論值の 2.5 2.8 倍の過剩空気が必要であるので, 燃焼に必要な空気量は, 塩化ビニル，ポリエチンンの場 合，それぞれ約 $11.0 \mathrm{Nm}^{3} / \mathrm{kg}$ ，約 $29.0 \mathrm{Nm}^{3} / \mathrm{kg}$ とかな りの量が必要となる。

\section{3. 焼却処理上の問題点}

\section{3-1. 高分子系廃棄物の性状}

\section{3-1-1. 多種多様性}

プラスチックを主とする高分子系廃棄物は，その種類 が非常に多く，その種類によって然焼特性飞かなりの差 違がある。高分子系の中には固体以外飞液体のるのも市 り，燃焼形態が異なるばかりでなく，発熱量の違いから 燃焼化要する空気量も変わる。プラステック廃葉物の場 合，旮れら特性の異なる数種以上の混合物が普通で，と くに一般ゴミから分別収集されるような時には，他の物 質も混り，かなり複雑な混合廃葉物となる。一力，プラ スチックを分別，選別することは技術的にる困難である ので，焼却师はこれら種類の多い混合プラスチックを， 十分燃焼処理できるものでなければならない。

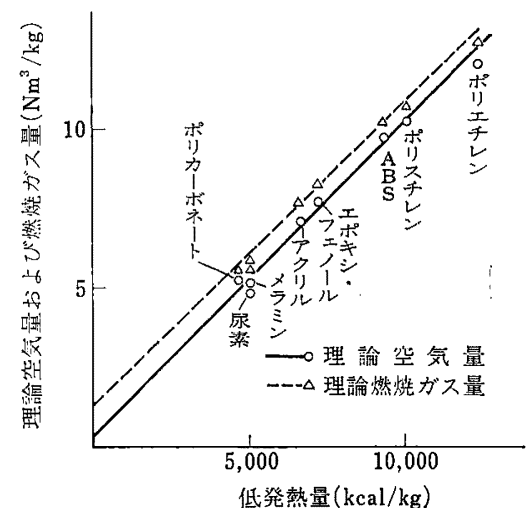

第 2 図プラスチックの低発熱量と 理論空気量・燃焼ガス量

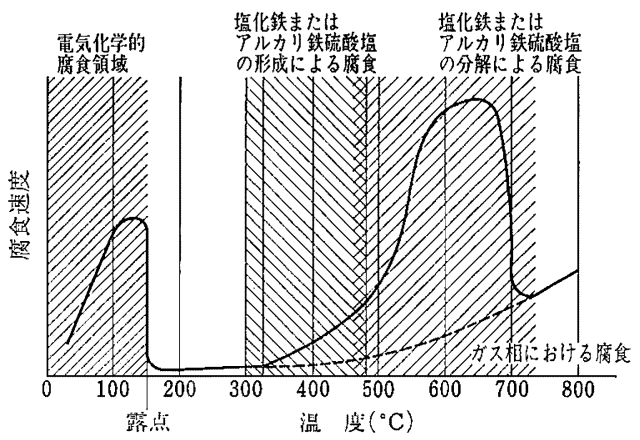

第 3 図腐食速の管壁温度による変化

\section{3-1-2. 廃盲物の形状}

プラスチック廃率物はその形状がざざまで，板状， フィルム状, 函状, 棒状, 塊状, 粉状, 泥状など千变万 化であり，大きさる小は食器, 電気部品から大は建築材 料，車両，船なぞの材料に至るまでいるいろである。こ れら複雑な廃㩽物を焼却処理するには，破哗などの前処 理をして，供給材料の均一化をはかることが望ましい。

\section{3-2. 焼却の問題点}

\section{3-2-1. 有害ガスの発生}

プラステック燃燒により発生する有害ガスは主として 塩化ビニルが熱分解によって生ずる多量の塩化水素であ る。不完全燃焼に上り発生する CO, 炭化水素, シアン 化水素拉よびススももちろん公害のもとになるが，これ らは完全燃焼技術によって解決できる。しかしながら， 塩化水素性高温でも分解せず，大気中で泠却されて塩酸 ミストとなり大きな公害のもとになる。このようなこと から，プラスチック公害は塩ビ公害をるって代表される と考党られるくらいである。一方，プラスチック中に含 亲れている安定剈，顔料として鉛，カドミウムも燃焼に よってほとんど大半がガス中含まれて排出する。これ らの重金属類拈よび塩化水素を燃焼ガス中から除去する ことが必要である。

\section{3-2-2. ガスによる腐食}

然焼ガス中の塩化水素は低温，高温いずれの領域にお 
いても金属対し激しい腐食を起こす。第 3 図は塩酸, 硫酸ガスの應食速度の管壁温黀に上る变化曲線を示す。 塩酸ガスによる金属への應食は露点以下の低温領域での 電気化学的腐食と $300^{\circ} \mathrm{C}$ 以上の高温領域法将る塩化 鉄形成敊よび分解汇起因する腐食である。この高温領域 ではガス相での應食によるより，金属表面化推積する圧 中の塩化鉄のため図のように大きな腐食性を示す。した がって燃燁ガス中の金属の表面を露点以上から $300^{\circ} \mathrm{C}$ ぐらいまでの間に保つことが腐食の防止策である。

\section{3-2-3. 高温燃焼}

プラステックは発熱量が普通のゴミに比べて数倍も高 く, 4,000 11,000 kcal/ kg ぐらいである。したがって 燃焼により炬内は非常に高温となりやすい。プラスチッ クの場合, 完全燃焼の適温は $1,000^{\circ} \mathrm{C}$ 以上であるが, 炉温が $1,200^{\circ} \mathrm{C}$ 以上飞上昇するとクリンカーが発生し たり，炉材の焼損をきたすとか障害ができるので，炉温 のコントロールが必要である。

\section{3-2-4. 黑煙の愽生}

プラスチックは燃焼に際し多量の筀気を必要とする が，この空気と分解発生した可燃性のガスとの接触が十 分でなかったり，供給空気量の不足の場合などに不完全 燃焼が起こり，黑歷(スス)を発生する。るた空気の過剩 送入や材料投入時の侵入空気のため炉温が低下し不完全

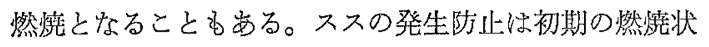
態で空気の適正な送入とガスとの接触をよくして完全然 焼を行なって防止するか，再燃焼室で不完全燃焼がスを さらに高温で完全に再然焼させる方法がよい。

\section{3-2-5。溶融による障害}

熟可塑性の大部分は熱によって溶けたり，軟化したり する。火格子のある炉では, 溶りたプラスチックが火格 子を閉塞させたり，火格子間を流下して，下で然光火格 子を焼損したりする。このようなことから燒却炉は一般 飞平床型式を採用することが多い。をた，材料の供給口 汇溶融した材料が閉塞を起こしたり，逆火などのトラブ ルを起こしやすい。

\section{4. 焼却炉の条件}

以上の問題点を解決する理想的な高分子系廃棄物の焼 却炉としての条件は

\section{4-1. 連続供給方式であるこよ}

炉内での完全燃焼状態を維持するためには，炉温，供 給空気量を一定に保ち，発生ガスと空気の接触をよくす ることが条件であるが，そのため性供給されるプラス

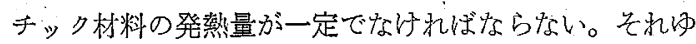
光材料は自動連続供給方式とし，一定の均質な材料をで きるだけ連続供給することが望をしい。性質，形状の異 なる廃葉物を破确処理して粒度と質の均一化をはかるこ とが必要になってくる。

\section{4-2. 完全燃焼方式であること}

炬は一般に平床形式で火格子をさけ，燃焼室は主然焼

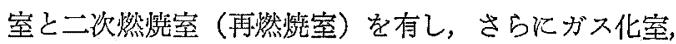
三次燃焼室と多室式にしたものもある。材料を高温ふん い気中でガス分解させ，発生ガスに適正な空気を効果的 飞接触させて完全燃焼させるので，空気とガスとの十分 なカキマゼ，接触がされるような工夫が必要である。主 燃焼室で不十分な不安全燃焼ガスを丽燃焼室でさらに空 気を与兄，完全然焼を完遂させる方式が望ましい。

\section{4-3. 排ガス処理が十分であること}

ばいじんや有害ガスはそのまま放出すると大きな公害 となるので排ガス処理は十分でなければならないが，問 題の塩化水素は水またはアルカリ溶淮を使用した湿式ガ ス洗浄装置によならければ除去は期待できない。湿式ガ ス洗浄装置は, 吸収塔，充テン塔，多段式，ベンチュリー ・スクラバーなど種々の形式のものがある。これらは塩 化水㬌のみならず $\mathrm{SO}_{x}$, 鉛, カドミウムなどの重金属ミ ストや，ばいじんも除去できるるのが多い。除去效率は それらの装置の段数, 水の使用量, 気液接触効獄によ。 て変わるが，十分二次公害を防止しらる高效率のものを 使用する必要がある。さらにこれらの湿式ガス洗浄装置 浊有害成分である塩酸を多量に含んで排水を排出する。 排水処理は十分なものを具僃し，循環再使用するのがよ く, 一部放流水火対しては, 水質污渴の公害防止のため, 中和処理はもらろん，場合によっては重金属の溶解濃度 を，規制值を十分渶足する水質にすることが肝要である。

\section{4-4. 構造的}

炉は普通レンガ樍構造とするが, $1,100^{\circ} \mathrm{C}$ 以上の高温 に十分耐觉らる耐火レンガを使用し，炉内での金属構造 物はできるだけ避け，使用する場合は金属壁面温度を腐

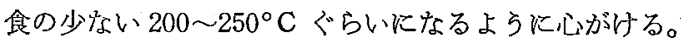
ボイラーケど，余熱利用のため廃ガス中に設ける場合も 管壁温度を適正にして腐食をさける必要がある。

\section{5. プラスチック焼却炉}

以上の条件を満足する焼却炬として關発された恼の一 例について述べる。第 4 図はその構造を示す。すらかじ め破砕され，一定粒度に調整されたプラステックくずは ホッパーに投入されると，逨続自動供給装置によって一 定量ずつ連続的に炉内の高温ふんい気の中へ送り込まれ 散布される。炬は始動时, 炬温上曻のため助燃バーナー により加熱されるが，材料の供給とともに助然はやめ， 自燃海当。炬は一次，二次，三次燃焼室から成り，各 室は炉壁没設られた調節可能な多数の空気欦込くズル を有して招り，炉内に必要かつ十分な空気を強力に吹き 込み，十分なカキマゼ效果を期している。一次然焼室へ 散布された材料は，空気の十分な供給を得て，短時間に ほとんど燃焼を完了するが，二次，三次燃焼室を経過し 


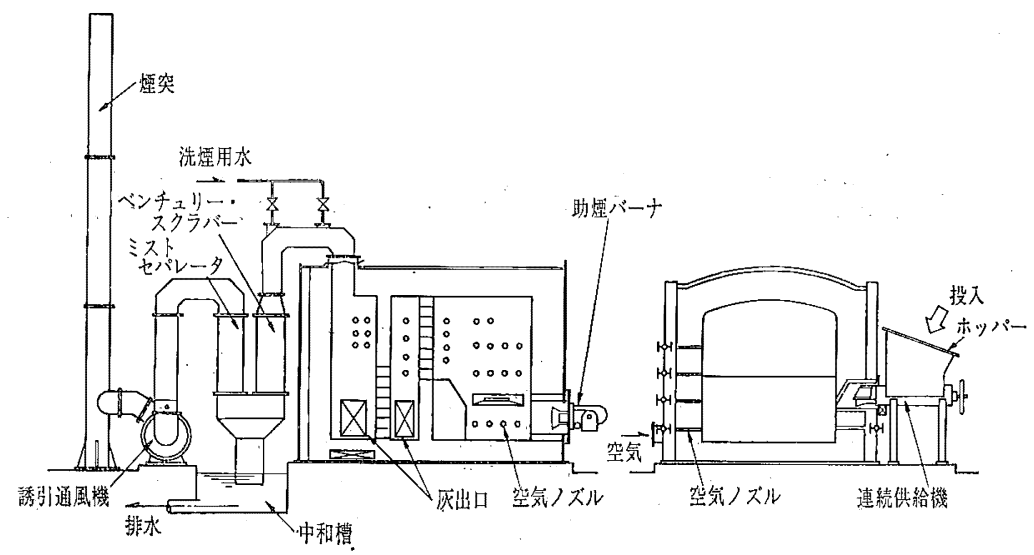

第 4 図 プラスチック廃钭物焼却炉

第 3 表 塩化ビニル（硬質）焼却テスト成組

(S. 46. 2. 25)

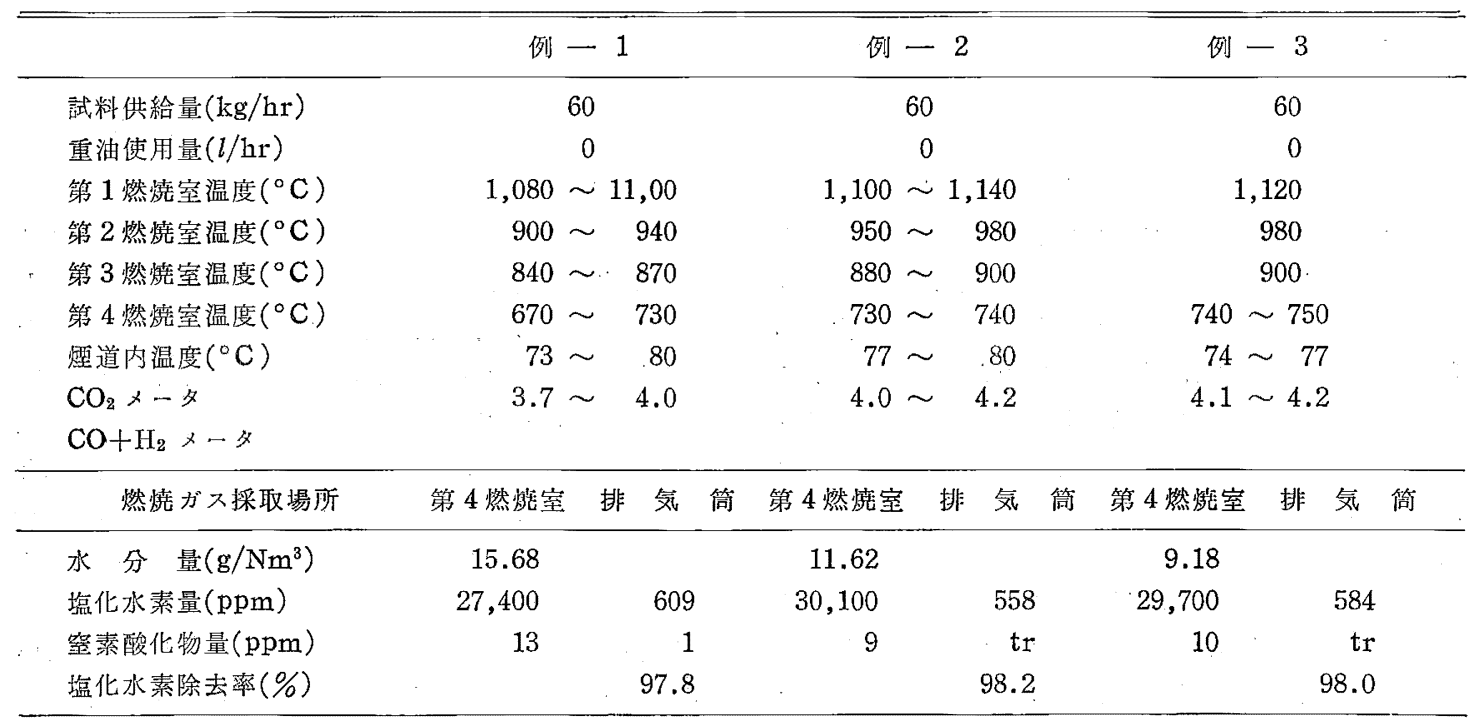

てさらに再燃焼し完全燃焼状態を完遂する。

燃焼排ガス中に，塩ビ焼却による塩化水素を含んでい る場合, ベンチュリー・スクラバーを用いて，水をたは アルカリ溶液でガスを洗浄し，然焼ガス中の塩化水素と 同時にばいじんを除去し，ガスは誘引通風機を経て㾏突 から放出される。ベンチュリー・ズクラバーの排水性, 水洗浄の場合, 塩酸による酸性を呈するので, 中和槽に 導き，石炭石による中和と沈殿処理ののち，大部分は循 環使用し，一部は放流する。

第 3 表はこの焼却炉を使用して，硬質塩化ビニルだけ を焼却処理した時の成績を示す。塩化ビニルは燃焼に際 して多量の不然性の塩化水素ガスを出し,このため, 完 全然筧がしにくいとされているが，この炤で助然料を使 用せず自燃で十分完全焼却できた。炉内温度は $1,100^{\circ} \mathrm{C}$ 前後が適当で，一次然焼室でほとんど然暁を終らせてい る。塩化ビニル專焼の場合は燃焼ガス中の塩化水素量は
$30,000 \mathrm{ppm}$ 前後と非常に高い濃度となった。これをべ ンチュリー・スクラバーで約 $98 \%$ の高効率で除去でき てる，残留塩化水素濃度は 550 600.ppm あり，煙突排 出濃度を数十 ppm 以下にするために恃 2 段式のベンテ ニリー・スクラバーを使用しなければならない。

このよらにプラスチック焼却の問題恃，塩化ビニル然 焼の問題と考学てよく, 塩ビの処理上の問題点の解決が より安全, 確実なプラスチックの処理とい方る。塩ビの 害のもとである塩化水素をうまく料理することが，この 問題の最も重要な要素になってくる。

このことから，塩どを含もプラスチックを低温乾留で 脱塩酸処理し，塩酸を出しつくした残留物を焼却処理し 塩酸ガスは塩酸として回収する力法や，ポリ浴中でプラ スチックを乾留，ガス化させ，ガス中の塩酸を回収除去 する方法など，いろいろな新しい処理技術が確立されて きている。 